\title{
The Van der Woude syndrome (dominantly inherited lip pits and clefts)
}

\author{
ALBERT SCHINZEL AND MARTIN KLÄUSLER \\ From the Institute of Medical Genetics, University of Zürich, Switzerland.
}

A patient with symmetrical lower lip pits with or without cleft lip or palate is most likely to be the carrier of a dominant gene that causes the syndrome of lip pits and clefts or Van der Woude syndrome. Familial occurrence of lower lip pits and clefts was first described by Demarquay in $1845 .^{1}$ Watanabe $e t$ $a l^{2}$ reviewed some 100 cases in 1951 , and Van der Woude delineated the syndrome in $1954 .^{3}$ Further important contributions came from Cervenka et $a l^{4}{ }^{4}$ who presented 66 personally observed cases and reviewed some 450 others, and Rintala and Ranta, ${ }^{5}$ who studied the incidence among cleft cases from the Finnish malformation registry. Finally, Burdick et $a l^{6}$ performed a genetic analysis of 864 cases.

\section{Incidence}

Burdick et al, ${ }^{6}$ from data from 864 cases, calculated a mutation rate of about $1.8 \times 10^{-5}$. In Zürich,

Received for publication 17 March 1986 Accepted for publication 24 March 1986.
Kläusler ${ }^{7}$ found that about half of the probands ascertained through clefts represented fresh mutations. In Finland, Rintala and Ranta ${ }^{5}$ estimated the incidence of gene carriers among livebirths to be 1 in 33600 with a prevalence in the general population of about 1 in 60000 (about $2 \%$ of all clefts are associated with lower lip pits, the incidence of all clefts is about 1 in 650 , and about 70 to $80 \%$ of patients carrying the Van der Woude gene have some kind of cleft). The $2 \%$ association of clefts with pits is higher than suggested in previous studies, but this probably reflects better ascertainment of cases with microforms of pits.

\section{Clinical aspects (figs 1 to 4 )}

The cardinal feature present in over $80 \%$ of carriers of the gene is symmetrical pits or eminences in the vermilion border of the lower lip about $\frac{1}{2} \mathrm{~cm}$ from the midline. The pits are localised at the end of a canal $1 \mathrm{~mm}$ to $2.5 \mathrm{~cm}$ in length, which runs through the
FIG 1 Lip pits and left cleft lip and palate in a 6 month old patient. 


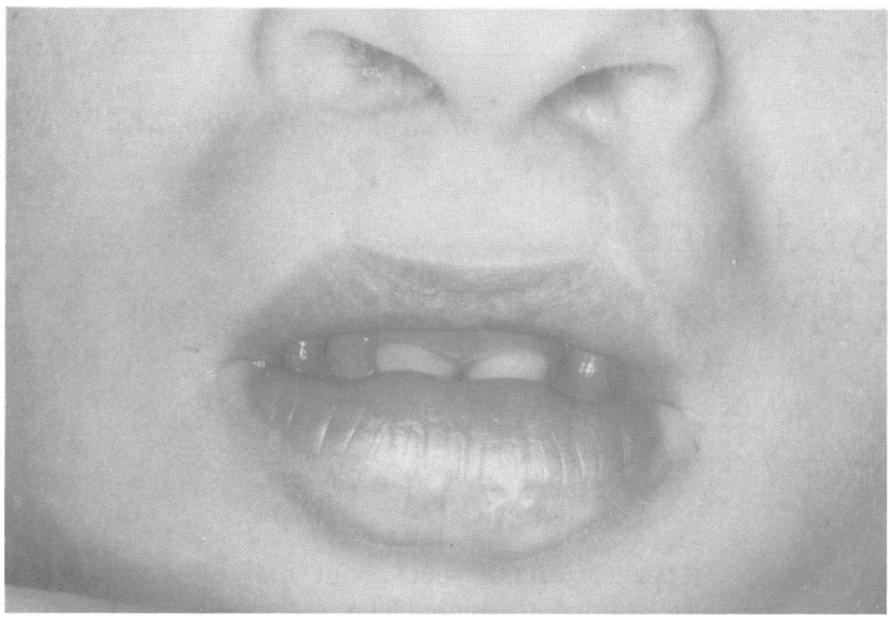

FIG 2 Bilaterally excised lip pits and operated cleft lip in a 4 year old boy (case 2 from Kläusler ${ }^{7}$ ).

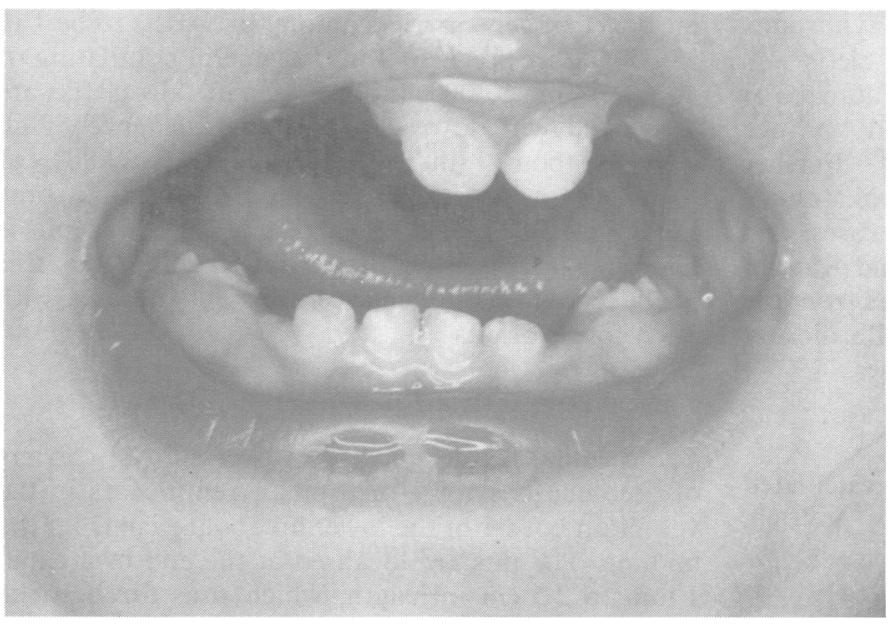

FIG 3 Bilateral symmetrical lip pits in an 18 month old girl (case 31 from Kläusler 7 ).

FIG 4 Microforms of hilateral pits at the inner margins of the vermilion of the lower lip in a 70 year old woman who was not aware of being affected (case 46 from Kläusler ${ }^{7}$ ). 
orbicularis oris muscle and may contain heterotopic salivary glands. The pits may be asymmetrical due to alteration of lip morphology or asymmetrical size or both. These pits are associated with clefts in about half of the gene carriers. Among these, two-thirds have cleft lip or cleft lip and palate and one-third have cleft palate alone.

Hypodontia is present in about 10 to $20 \%$ of gene carriers (third molars excluded) and may occasionally represent the sole expression of the gene. The second incisors and second molars are mostly affected in the deciduous or permanent teeth or both.

Microforms, which represent a mild expression of the gene, may include a verrucous eminence in the lower lip, either uni- or bilaterally, without secretion, submucous cleft palate, and bifid uvula. These forms are mostly found only on detailed examination of family members of affected probands. Some patients are themselves not aware of being affected.

\section{Differential diagnosis}

POPLITEAL PTERYGIUM SYNDROME

The major features of this syndrome include, with decreasing frequency, popliteal pterygia, facial clefts, abnormal genitalia (cryptorchidism and bifid scrotum in males, hypoplasia of the labia majora and uterus in females), lip pits, syndactyly of the toes or fingers or both, other minor distal limb anomalies, and oral synechiae. This syndrome is probably dominantly inherited with very variable expression. In a few instances, a parent of an affected proband has had only a cleft with or without lower lip pits. ${ }^{78}$ Thus, patients with pits and clefts have a small risk of having offspring affected with, in addition to their parent's features, popliteal pterygia and other signs of this syndrome.

\section{THE OROFACIODIGITAL SYNDROME}

TYPE I

This syndrome may rarely present with lower lip pits and clefts. Differentiation from both the Van der Woude and popliteal pterygium syndromes will usually be easy from the orodigital findings.

\section{Management/treatment}

Management of clefts in these patients is no different from that in other cleft patients. Exstirpation of the canals including the salivary tissue or electrocoagulation of pits can be considered for aesthetic or functional reasons (trauma, infection), but attention must be paid to the orbicularis oris muscle. In many instances it is better to refrain from surgery.

\section{Pathogenesis}

Incomplete reduction during embryogenesis of the naturally occurring sulci laterales of the lower lip, which normally occurs at the same time as fusion of the lip and palate at about day 40 to 50 , is thought to be the cause of the pits. Thus, a genetically determined defective formation of tissue in this area might lead to either pits or clefts or both.

\section{Inheritance and aetiological factors}

This is an autosomal dominant condition with a wide range of expression and full or only slightly reduced penetrance. Probably monozygotic female twins reported were concordant for lip pits but discordant for left cleft lip. ${ }^{4}$ Sex distribution is equal and differences in expression are not sex related. The distribution of clefts parallels that in the general population except for the sex difference in the latter. Submucous clefts and bifid uvula are only occasionally found. According to most reports, there is a slight tendency for more severely affected parents to have more severely affected children and less severely affected parents to have less severely affected children.

The incidence of new mutations in cases with clefts is somewhere between $1 / 3^{5}$ and $1 / 2,7$ but is not known for pits alone. Published reports are strongly biased towards large pedigrees. A paternal age effect for new mutations has so far not been found.

Better knowledge of microforms of pits, submucous clefts, bifid uvula, and missing teeth has led to a fall in reported instances of non-penetrance to almost zero in the last few years. ${ }^{7}$ Carriers of the gene may, rarely, show clefts without pits; these cases represent a small group of cleft patients with a high recurrence risk and underline the need for specific questions and examination for lip pits including microforms in relatives of cleft patients at genetic counselling.

In spite of several studies in large families, no gene linkage has yet been established and the localisation of the gene is not known. The variable expression of the gene is probably caused by the action of other genes. Kläusler ${ }^{7}$ found no difference in pedigrees, parental ages, birth orders, pregnancy histories, exposures to teratogens, and birth weights between carriers with and without clefts.

We wish to thank Drs W Gnoinski and M Hotz for referring most patients for the present study and the Stiftung für wissenschaftliche Forschung an der Universität Zürich for financial support.

\footnotetext{
References

1 Demarquay JN. Quelques considérations sur le bec-de-lièvre. $G a=$ Med Paris 1845:13:52-3.

2 Watanabe Y. Hakushi I. Otake M. Tomida K. Congenital fistulas of the lower lip. Report of five cases with special reference to the etiology. Oral Surg 1951:4:709-22.
} 
${ }^{3}$ Van der Woude A. Fistula labii inferioris congenita and its association with cleft lip and palate. Am J Hum Genet 1954;6:244-56.

${ }^{4}$ Cervenka J, Gorlin RJ. Anderson VE. The syndrome of pits of the lower lip and cleft lip and/or palate. Genetic considerations. Am J Hum Genet 1967;19:416-32.

5 Rintala AE, Ranta R. Lower lip sinuses. I. Epidemiology. microforms and transverse sulci. Br J Plast Surg 1981;34:26-30.

- Burdick AB, Bixler D, Puckett CL. Genetic analysis in families with Van der Woude syndrome. J Craniofac Genet Dev Biol 1985;5:181-208.

${ }^{7}$ Kläusler M. Unterlippenfisteln und Gesichtsspalten mit autosomal- dominantem Erhgang. Eine Studie an 56 Fällen. Zürich: Diss. 1986

8 Rintala AE. Lahti AY, Gylling S. Congenital sinuses of the lower lip in connection with cleft lip and palate. Clefi Palate $J$ 1970:7:336-45.

Correspondence and request for reprints to Professor A Schinzel, Institut für Medizinische Genetik der Universität Zürich, Rämistrasse 74, CH-8001 Zürich, Switzerland. 